\title{
STUDY OF THE PREVALENCE OF Capillaria hepatica IN HUMANS AND RODENTS IN AN URBAN AREA OF THE CITY OF PORTO VELHO, RONDÔNIA, BRAZIL
}

\author{
Elierson José Gomes da ROCHA(1), Sérgio de Almeida BASANO(1), Márcia Maria de SOUZA(2), Eduardo Resende HONDA(3), \\ Márcio Botelho de CASTRO(4), Edson Moleta COLODEL(5), Jéssica Carolinne Damasceno e SILVA(1), Lauro Prado BARROS(1), \\ Elisa Sousa RODRIGUES(1) \& Luís Marcelo Aranha CAMARGO(6)
}

\begin{abstract}
SUMMARY
Introduction: Hepatic capillariosis, caused by Capillaria hepatica (Calodium hepaticum) (Bancroft, 1893), Travassos, 1915 (Nematoda, Trichinelloidea, Capillariidae), is a common zoonosis in rodents but is rare in humans. Seventy-two cases in humans have been reported worldwide since the first case was described by MACARTHUR in $1924^{17,27}$. This study aimed to determine the prevalence of Capillaria hepatica in humans and rodents in an urban area of Porto Velho, the capital of Rondônia, in Brazil. Methods: After conducting a census of the area, 490 residents were randomly selected, and, after signing a term of consent, provided blood samples that were screened for anti-Capillaria hepatica antibodies. Simultaneously, rats were captured to assess the prevalence of this parasite in rodents by histopathological examination in liver sections. Results: A prevalence of $1.8 \%$ was found among residents who had specific antibodies at a dilution of 1:150, indicating exposure to parasite eggs; $0.8 \%$ of the subjects also had positive titers at a dilution of 1:400, indicating true infection. The prevalence in rats was $2 \%$. Conclusions: The prevalence of infection with this parasite among humans and rats was low. While the prevalence encountered among humans was within the limits reported in the literature, the prevalence among rodents was much lower.
\end{abstract}

KEYWORDS: Capillariasis; Capillaria hepatica; Rondônia; Amazônia.

\section{INTRODUCTION}

Capillaria hepatica has a wide geographic distribution and is able to colonize a diverse array of environments and mammals, including wild and domestic rodents.

Certain authors reported finding Capillaria sp. eggs in canine coprolites from 6,500 BC in Patagonia ${ }^{18}$, and certain studies reported evidence of human infections in France in the Neolithic and Paleolithic periods $s^{3}$ and in the region that is now Belgium in the $16^{\text {th }}$ century and the Middle Ages ${ }^{13,35}$. This parasite has been detected from the icy regions of Canada, where studies have shown that eggs can withstand the six winter months ${ }^{16}$, to Africa, Asia and South America, passing through the US and Europe ${ }^{17}$.

This nematode has a unique esophageal structure consisting of specialized cells known as stichocytes (characteristic of the superfamily
Trichinelloidea). The adult forms of this parasite are very slender, small and morphologically similar to parasites of the genus Trichuris that live in the hepatic parenchyma. The male is 30 to $50 \mathrm{~mm} \mathrm{long}^{42}$ and the eggs are bi-operculate with a tray-like shape ${ }^{36}$. The completion of the life cycle of the worm does not depend on an intermediary host as embryonated eggs are ingested directly from the soil or animal carcasses. L1 larvae hatch in the cecum, penetrate the mucosa, travel to the portal system and establish themselves in the hepatic parenchyma, where they develop from L2 to L4 larvae and finally into the adult form. Fertilized eggs are released in groups around the female, and the female perishes after an average period of 30 days. The viable, but still immature eggs remain for up to 120 days. For embryogenesis to occur, the egg must be outside the host, which can occur: a) when the host dies and its carcass disintegrates and/or b) when the viscera of the host are ingested by predators; in the latter case, the non-embryonated eggs are eliminated in the feces and thus returned to the environment and embryonate ${ }^{12,25}$. There is also evidence that arthropods (flies and beetles) can spread eggs from the soil ${ }^{29,30,32}$.

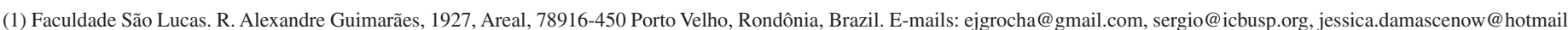
com, lauroprabarros@hotmail.com, elisa_sr90@ hotmail.com

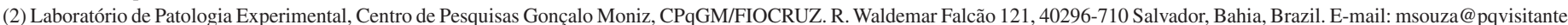
bahia.fiocruz.br

(3) Laboratório Central de Saúde Pública de Rondônia, LACEN/RO. R. Anita Garibaldi 4130, 78903-770 Porto Velho, Rondônia, Brazil. E-mail: eduardohonda@ hotmail.com

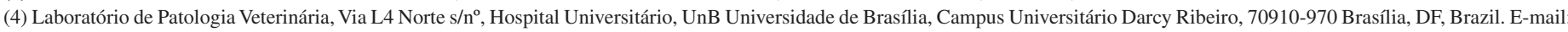
mbcastro2005@yahoo.com.br

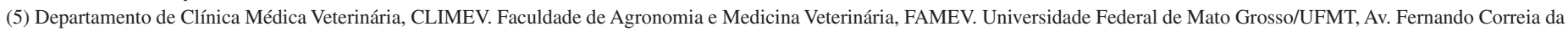
Costa 2367, 78068-900 Cuiabá, Mato Grosso, Brazil. E-mail: moleta@gmail.com

(6) University of Sao Paulo. Rua Francisco Prestes 2827, Monte Negro, 78068-900 Rondonia, Brazil. E-mail: spider@icbusp.org

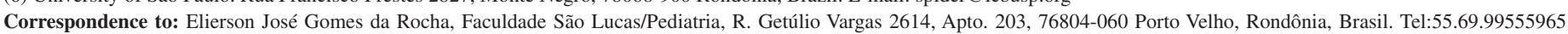

E-mail: ejgrocha@gmail.com 


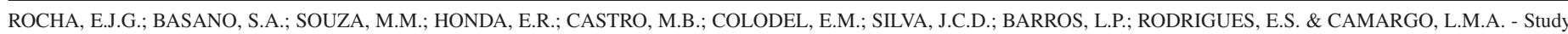
of the prevalence of Capillaria hepatica in humans and rodents in an urban area of the city of Porto Velho, Rondônia, Brazil. Rev. Inst. Med. Trop. Sao Paulo, 57(1): 39-46, 2015.

Seventy-two cases of hepatic capillariosis have been reported in humans in the literature ${ }^{17}$ since the first case was described by MACARTHUR in $1924^{27}$. Infections have been documented on all continents, and five were reported in $\mathrm{Brazil}^{33,34,39}$. In addition, $C$. hepatica eggs have reportedly been found in the feces of Suruí Indians ${ }^{9}$, ethnicities of the Guaporé-Mamoré valley ${ }^{38}$ and a riverine population in Rondônia, Brazil ${ }^{4}$. As a rule, the infection produces the classical triad of fever, hepatomegaly and eosinophilia and can progress to death if left untreated ${ }^{34,39}$.

Some sero-epidemiological surveys of hepatic capillariasis have been performed: JUNCKER-VOSS et al. ${ }^{25}$ surveyed employees of the Vienna zoo and encountered a total prevalence of $1.8 \%$, and GALVÃO ${ }^{21}$ documented a prevalence of approximately $1.6 \%$ in Salvador, Bahia. CAMARGO et al., documented a $C$. hepatica seroprevalence of $0.8 \%$ in the local riverine population of Rio Preto at the intersection of the Machado and Madeira Rivers in the state of Rondônia in the Amazonian Region of Brazil (300 km away from Porto Velho, the capital city of Rondônia) $)^{4}$.

The logical follow-up to the study of CAMARGO et al. $(2010)^{4}$ would be to assess the seroprevalence of this parasitic disease in the urban area of Porto Velho, a city that suffers from many urban problems, such as unhygienic living conditions that force many of its inhabitants to coexist with a large population of domestic rats (an important reservoir for the disease in urban areas) $)^{19}$. This study aimed to verify the findings of CAMARGO et al. ${ }^{4}$ and propose specific intervention measures.

Because adult worms and their eggs remain confined to the liver, they are not normally eliminated with feces. Eggs are sometimes found in the stool of "spurious carriers" (i.e., those that swallowed immature eggs in the viscera of other animals) that are not necessarily sick. This makes the diagnosis of capillariasis somewhat more complex. However, available serological techniques (Enzyme-Linked Immunosorbent Assay - ELISA and indirect immunofluorescence - IFI) with different antigens ${ }^{1,24}$ can identify "spurious carriers" of $C$. hepatica or diseased individuals while ruling out cross-reactions with other similar helminths ${ }^{22,24}$.

Because this disease is seldom suspected, it is thought that less severe cases are rarely detected ${ }^{2,24}$. Furthermore, clinical manifestations of mild cases are likely to produce signs and symptoms common to other pathologies. Therefore, the detection of these cases will heavily depend on the degree to which $C$. hepatica infection is suspected.

No consensus exists on the treatment of this disease. CHEETHAM \& MARKUS ${ }^{6}$ used mebendazole and albendazole in an experimental rat model and showed that these drugs prevented oviposition in the hepatic parenchyma. EL GEBALY et al. and EL NASSERY et al. ${ }^{10,11}$ successfully used ivermectin and mebendazole in an experimental model to stop larvae from developing into adult form and thus prevent oviposition. SAWAMURA et al. ${ }^{39}$ successfully treated three infected patients with mebendazole and albendazole.

\section{GENERAL AIM}

The objective of this work was to study the prevalence of $C$. hepatica infection in humans and rodents in the urban area of Porto Velho, the capital of the Northern Brazilian state of Rondônia.

\section{METHODS}

Ethical parameters: All procedures described and performed in this study were approved by the Ethics Committee on Research with Human Beings of the Biomedical Sciences Institute of the University of São Paulo through process 1051/ICB and by the Ethics Committee on Animal Use (Comissão de Ética no uso de Animais - CEUA) of the same institute, according to the protocol registered under number 149 on page 136 of book 02 .

Study site: The study took place in the urban area of the Tucumanzal district of the municipality of Porto Velho, Rondônia, Brazil. To improve the distribution of samples and participants in this study, the area was divided into five subareas: AO, A1, A2, A3 and A4 (Table 1). The region chosen for the study has an epidemiological profile that is compatible with the transmission of $C$. hepatica ${ }^{19-21}$ : it is an old district of slums populated by low/medium income residents and has irregular garbage collection and inadequate sanitation.

\section{Table 1}

Sample stratified random sub-areas, the total area of study. Tucumanzal district, city of Porto Velho, Rondônia, 2011

\begin{tabular}{lccc}
\hline Subarea & No. Inhabitants & Sample & $\%$ (sample) \\
\hline AO & 323 & 66 & 13.5 \\
A1 & 546 & 117 & 23.9 \\
A2 & 442 & 90 & 18.4 \\
A3 & 301 & 66 & 13.5 \\
A4 & 737 & 151 & 30.7 \\
\hline Total & 2,349 & 490 & 100 \\
\hline
\end{tabular}

A UBS (Unidade Básica de Saúde - Basic Health Unit), a college and a variety of commercial establishments are found in the area.

Census: A census of the population residing in the study area (Tucumanzal District, city of Porto Velho (846'44.9'S 63'53'43.8'W - Google Maps accessed on 03/04/2014), was conducted during the months of February and March 2011. A total of 2,349 inhabitants were catalogued, and the following information was gathered from each inhabitant: name, monthly family income, address, age, gender, information about the sanitation conditions of households, ingestion of game meat and time residing in the area.

A sample size calculation was performed using the appropriate statistical analysis in the Open Epi software (Open Source Epidemiologic for Public Health) version 2.3.1 (www.openepi.com accessed on $10 / 01 / 2011$ ). From a total of 2,349 registered inhabitants, given an estimated prevalence of $2 \%$ and a confidence limit of $5 \%$, a sample size (N) of 383 individuals was obtained. This sample size was inflated by $30 \%$ to compensate for potential drop-out or refusal to participate, thus raising the total to 498 inhabitants. The sample was randomized using the Random Number Generator program (www.random.org accessed on 10/01/2011). Blood samples were collected from 490 of 498 randomly selected individuals (Table 1).

The population was willing to provide blood samples, most likely because health care in the region is lacking. To avoid concentrating the 


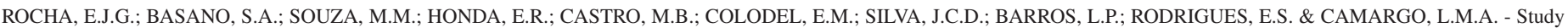
of the prevalence of Capillaria hepatica in humans and rodents in an urban area of the city of Porto Velho, Rondônia, Brazil. Rev. Inst. Med. Trop. Sao Paulo, 57(1): 39-46, 2015.

sampling within a single region of the district, the sample was randomly drawn from five subareas in proportion to the population of each subarea. This process resulted in a stratified random sample.

Human blood collection: The blood of the 490 volunteers was collected according to the following methodology. First, information on the study and the parasite was provided to the residents; in addition, participants received an informational leaflet. Next, pre-registered residents - who had been randomly selected and agreed to take part in the study - signed an Informed Term of Consent. Residents then underwent a general clinical examination, and blood was collected from the cubital fossa after the collection site was disinfected with $70 \%$ alcohol and a tourniquet was placed on the proximal arm region using a latex strap. The collected blood was allowed to stand to coagulate and then centrifuged at 5,000 RPM for 10 minutes, and the serum was aliquoted into PVC tubes and stored at $-20{ }^{\circ} \mathrm{C}$ until the time of analysis.

Serological technique: The technique previously proposed by ASSIS et al. ${ }^{1}$ was used: serum samples were diluted in $50 \%$ phosphate buffered saline (PBS) solution up to a concentration of 1:150 and tested using histological sections of rat livers containing $C$. hepatica worms and eggs embedded in paraffin supplied by the LAPEX-FIOCRUZ Brazilian government laboratory. Seropositive samples at a dilution of 1:150 were classified as either weakly positive (PI), moderately positive (PII) or strongly positive (PIII) according to the intensity of fluorescence assessed by two different examiners. Serum samples considered either moderately or strongly positive at a dilution of 1:150 were tested again at a dilution of 1:400, i.e., at the highest dilution used as a cut-off point for the elimination of false positives (spurious infections).

System for capturing rodents: Rodents were captured using 20 "Tomahawk" live traps $(20$ x 20 x $40 \mathrm{~cm})$ with banana, bread and peanuts as bait. All traps were mounted and remained active from 6:00 pm on Wednesday to $6: 00 \mathrm{pm}$ on Friday. Traps were checked and bait was replaced every 12 hours. If rodents were found in the traps at inspection times, they were sedated until death. These capture activities took place over a period of nine months. The traps were placed along a line of 10 points with approximately two traps per point; traps were laid on the ground and in bushes or trees up to $2 \mathrm{~m}$ high 20 to $40 \mathrm{~m}$ apart, depending on the irregularity of the terrain.

Sedation of the rodents: After rodents were captured, the animals were sedated using ketamine $(10 \mathrm{mg} / \mathrm{kg})$ and xylazine $(1 \mathrm{mg} / \mathrm{kg})$ using lethal doses of the same sedatives ${ }^{16}$. Liver samples were then collected and immediately stored in numbered tubes containing $10 \%$ buffered formaldehyde.

Slides were prepared by fixing the sample material to preserve tissue morphology, dehydrating the tissue in increasing concentrations of ethyl alcohol, cleaning the tissues in xylol, impregnating them with melted paraffin and embedding them. Afterwards, the tissues were cut with a microtome, stained and mounted. Slides were prepared using histological sections from liver samples of 50 rats (Rattus rattus and Rattus norvegicus).

Disposal of material: Sharp/cutting material was discarded in rigid containers while gloves and cotton were disposed of in 10-micrometerthick opaque white plastic garbage bags according to the the Brazilian Health Surveillance Agency for disposal.

\section{RESULTS}

Socio-economic conditions of the population: From an economic point of view, the large majority of the residents are workers with little or no specialization who perform manual labor in commerce, the public service, private companies or informally. Table 2 gives an overview of the population characteristics of the studied area. As can be seen, the sample is composed of people of low socioeconomic status, with an average monthly income of around US\$ 400 (up to twice the minimum wage). As a result, residents belong to classes D and $\mathrm{E}$ of the classification of the Brazilian Institute of Geography and Statistics i.e., they have low incomes (Table 2).

Table 2 shows the urban conditions in which they live. They have poor sanitation and these areas that are liable to flooding favor the proliferation of rats. An aggravating factor for the risk of spurious infections is the frequent ingestion of game meat and viscera by residents.

Table 2

Socio-economic, cultural and urban characteristics of the study area. Tucumanzal District, Porto Velho, Rondônia, 2012

\begin{tabular}{|c|c|c|c|c|c|}
\hline Subareas & A0 & A1 & $\mathrm{A} 2$ & A3 & A4 \\
\hline Total inhabitants & 323 & 546 & 442 & 301 & 737 \\
\hline Per capita income (MW) & Up to 1.5 & $<1.0$ & $<1.0$ & Up to 1.0 & Up to 1.0 \\
\hline Wastewater discharged to the stream & No & Yes & Yes & No & Yes \\
\hline Igarapé (tributary river) & No & Yes & $\mathrm{Yes}^{2}$ & No & Yes \\
\hline Households with river water catchment and/or sewage (\%) & 75 & 60 & 20 & 90 & 95 \\
\hline Households with running water (CAERD) (\%) & 95 & 85 & 60 & 95 & 90 \\
\hline Paved roads $(\%)$ & 95 & 90 & 75 & 100 & 100 \\
\hline Weekly garbage collection ${ }^{1}$ & 3 times & 3 to 4 times & 3 times $^{3}$ & 3 times & 3 to 5 times \\
\hline Game meat consumption among residents (\%) & 35 & 35 & 41.1 & 27.2 & 34.4 \\
\hline
\end{tabular}

${ }^{1}$ - Selective garbage collection was not mentioned. ${ }^{2}$ - Refers to inundation during rainfall. ${ }^{3}$ Garbage collection is not performed on some streets. MW: minimum wages. 


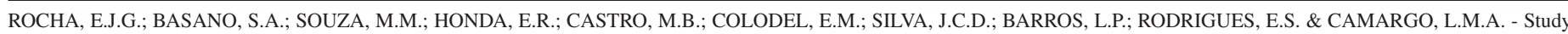
of the prevalence of Capillaria hepatica in humans and rodents in an urban area of the city of Porto Velho, Rondônia, Brazil. Rev. Inst. Med. Trop. Sao Paulo, 57(1): 39-46, 2015.

Material collected from rodents: Table 3 summarizes the results of anatomopathological studies of the livers of the 50 captured rats; the data are categorized by subareas.

Table 3

Anatomopathological analysis of the rat livers. Tucumanzal District, Porto Velho, Rondônia, 2012

\begin{tabular}{lcccc}
\hline Subareas & Total/Subarea & Necrosis & $\begin{array}{c}\text { Septal } \\
\text { Fibrosis }\end{array}$ & $\begin{array}{c}\text { Parasites } \\
\text { and/or eggs }\end{array}$ \\
\hline A0 & 07 & Zero & Zero & Zero \\
A1 & 11 & $03(27.3 \%)$ & $02(18.8 \%)$ & Zero \\
A2 & 05 & Zero & Zero & Zero \\
A3 & 15 & $04(26.6 \%)$ & Zero & Zero \\
A4 & 12 & $04(33.3 \%)$ & $02(16.6 \%)$ & $01(8.3 \%)$ \\
\hline Total & $\mathbf{5 0}$ & $\mathbf{1 1 ( 2 2 \% )}$ & $\mathbf{0 4 ( 8 \% )}$ & $\mathbf{0 1 ( 2 \% )}$ \\
\hline
\end{tabular}

In addition to being inspected for eggs and worms (which would confirm the infection beyond any doubt), tissue samples were also inspected for the presence of septal fibrosis (probable infection), focal fibrosis, necrosis and inflammation (suspected infection).

Several anatomopathological studies of the livers of rats infected by C. hepatica have shown that while the observed presence of parasite eggs and/or worms definitively confirms the infection, the presence of hepatic septal fibrosis is also an important characteristic that appears after the death and degeneration of worms in the presence of eggs ${ }^{14,37}$. Such a finding, though non-conclusive, would strongly suggest infection by $C$. hepatica.

Material collected from humans: Serology (IIF) of blood samples from the 490 residents of the selected area of Porto Velho was performed to quantify the prevalence of $C$. hepatica infection.

As observed in Table 4, nine of the 490 human blood samples were positive by IIF for $C$. hepatica at the 1:150 dilution (1.8\%); four of these also reacted positively at the $1: 400$ dilution $(0.8 \%)$ (two in subarea A1 and two in subarea A3).

An equal number of men and women tested positive by IIF at the 1:400 dilution; these individuals were aged 10-19 (one case), 20-29 (two cases) and above 50 (one case).

Table 4

Serology (IIF) results by subarea, gender and serum dilution. Tucumanzal District, Porto Velho, 2012

\begin{tabular}{lccc}
\hline Subarea & $\begin{array}{c}\text { Number of } \\
\text { Individuals }\end{array}$ & $\begin{array}{c}\text { Positive at } \\
1: 150 \text { dilution }\end{array}$ & $\begin{array}{c}\text { Positive at } \\
1: 400 \text { dilution }\end{array}$ \\
\hline Zero & 66 & 1 & Zero \\
A1 & 117 & 4 & 2 \\
A2 & 90 & Zero & Zero \\
A3 & 66 & 4 & 2 \\
A4 & 151 & Zero & Zero \\
\hline Total & $490(100 \%)$ & $9(1.8 \%)$ & $4(0.8 \%)$ \\
\hline
\end{tabular}

The following laboratory tests were further performed on the individuals with positive serology at the 1:400 dilution: complete blood count and measurement of levels of aspartate aminotransferase (ATS), alanine aminotransferase (ALT), bilirubin total and fractions. As observed in Table 5, only one of the four residents with positive serology at the 1:400 dilution displayed altered laboratory parameters, namely, a mild to moderate increase in her total and indirect bilirubin levels. All of these individuals underwent a liver ultrasound, but none of them displayed any abnormalities.

\section{DISCUSSION}

Although previously published studies show that the prevalence of C. hepatica in certain rodent species, tends to be high (between 56.5 and $89.3 \%)^{5,7,20,31}$, the prevalence of $C$. hepatica infection appears to be low among residents of the studied area and among rodents that live close to their dwellings.

To ascertain whether a rodent is infected with $C$. hepatica, eggs or worms must be found in its liver. In the present study, eggs and worms were detected in the liver of only one of the animals captured in subarea A4, which corresponds to a prevalence of $2 \%$. This animal also presented with septal fibrosis. Studies have shown that septal fibrosis occurs in practically all rats infected with $C$. hepatica $a^{5,14,22,37}$. FERREIRA $\&$ ANDRADE $^{14}$ stated that experimental $C$. hepatica infection in rats represents a good model for the study of liver septal fibrosis because all rats in their experiments developed septal fibrosis after the 40th day of parasite infection. A similar result was found by SANTOS et al. ${ }^{37}$.

In the study, three other animals had septal fibrosis, which could raise the prevalence among rodents to $8 \%$; however, $8 \%$ is still lower than the values encountered in other studies ${ }^{7}$. Seventeen animals in the present study also had non-specific inflammation, and eleven animals had marked necrotic areas that can be associated with infection by the parasite, although not a specific manifestation.

The low prevalence of infection in rodents in the study area (Table 4 ) is consistent with the low prevalence encountered among humans. As observed by SPRATT \& SINGLETON ${ }^{41}$, most $C$. hepatica infections in non-rodent mammals occur when these animals live near infected $R$. norvegicus populations ${ }^{5}$.

It is likely that the reduced size of the rat sample did not allow the present study to demonstrate the association between the presence of infected rodents and a high prevalence of parasite infection. It is important to try to understand why the prevalence of $C$. hepatica in rats in the urban region of Porto Velho was so low. Infection with this parasite occurs after the infected animal dies and its liver decays in the environment, thus releasing the eggs that become infective after a certain period of time. Once ingested by other animals, these eggs cause infection in a wide variety of species, including humans. The ingestion of eggs, even directly from the livers of infected animals, does not necessarily lead to infection, as the eggs must travel undamaged through the digestive tract, be released in the feces and reach the soil, where their maturation cycle is completed. The city of Porto Velho is located in a very rainy region with long daily episodes of high-volume rainfall. The site where the present study was conducted has streams that usually overflow, thus "washing out" the site and carrying much of the accumulated garbage to 


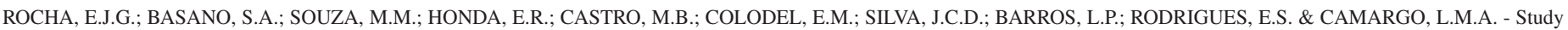
of the prevalence of Capillaria hepatica in humans and rodents in an urban area of the city of Porto Velho, Rondônia, Brazil. Rev. Inst. Med. Trop. Sao Paulo, 57(1): 39-46, 2015.

Table 5

Results of C. hepatica positive serology (IIF) residents (1:400). Tucumanzal District, Porto Velho, Rondônia, 2012

\begin{tabular}{|c|c|c|c|c|c|}
\hline \multirow{2}{*}{ Laboratory test } & \multicolumn{4}{|c|}{ Resident } & \multirow{2}{*}{ Reference Values } \\
\hline & 1 & 2 & 3 & 4 & \\
\hline Red blood cells $10^{6} / \mathrm{mm}^{3}$ & 4.85 & 4.81 & 5.24 & 5.18 & $4.1-6.0$ \\
\hline Hemoglobin g/dL & 13.9 & 14.3 & 13.6 & 15.6 & $12-18$ \\
\hline Hematocrit $\%$ & 41.7 & 43.8 & 42.3 & 45.8 & $37-54$ \\
\hline Leukocytes $10^{3} / \mathrm{mm}^{3}$ & 5.320 & 6.75 & 9.09 & 6.44 & $4-10$ \\
\hline Band cells \% & 2 & 2 & 2 & 1 & $0-4$ \\
\hline Segmented neutrophils $\%$ & 46 & 65 & 63 & 50 & $45-70$ \\
\hline Eosinophil's \% & 5 & 1 & 1 & 2 & $1-5$ \\
\hline Basophils \% & 0 & 0 & 0 & 0 & $0-2$ \\
\hline Typical lymphocytes \% & 38 & 29 & 29 & 37 & $20-40$ \\
\hline Atypical lymphocytes \% & 0 & 0 & 0 & 0 & $0-2$ \\
\hline Monocytes \% & 9 & 5 & 5 & 10 & $2-10$ \\
\hline Platelets $10^{3} / \mathrm{mm}^{3}$ & 235 & 197 & 323 & 336 & $150-450$ \\
\hline ATS U/L & 13 & 10 & 21 & 17 & $10-39$ \\
\hline ALT U/L & 12 & 11 & 23 & 13 & $10-37$ \\
\hline Total bilirubin mg/dL & 1 & 1.1 & 0.9 & 1.5 & 1.2 \\
\hline Direct bilirubin mg/dL & 0.2 & 0.2 & 0.2 & 0.2 & 0.4 \\
\hline Indirect bilirubin $\mathrm{mg} / \mathrm{dL}$ & 0.8 & 0.9 & 0.7 & 1.3 & 0.8 \\
\hline
\end{tabular}

the Madeira River channel. Therefore, animal carcasses do not remain in the environment; as a result, the spread of eggs and their ability to mature in an adequate environment is limited. It is possible that the study area represents a region where the disease has only recently been introduced instead of an endemic region where a high prevalence in rats was detected.

When the results obtained in the present study are compared with those of CAMARGO et al. ${ }^{4}$ in riverine populations of the state of Rondônia, it becomes clear that the riverine population experiences much higher rates of contamination than the urban population, but only with regard to the spurious infections. When the spurious infection rates (1:150 dilution) of both populations are compared $\left(\mathrm{x}^{2}=153.6\right.$ and $p<$ $0.0000001)$, it appears likely that the riverine population experiences much higher rates of spurious contamination (34.1\%) than the urban population (1.8\%), perhaps due to the ingestion of wild animal viscera. However, when the seroprevalence is analyzed at higher dilutions that are indicative of true infection (1:500 in the study of CAMARGO et al. and 1:400 in the present study), similar rates of approximately $0.8 \%$ are found in both populations $\left(\mathrm{x}^{2}=0.2289\right.$ and $\left.p=0.2161\right)$.

In reality, the data presented in this study corroborate the results of CAMARGO et al. ${ }^{4}$. Because the riverine population is characterized by low socio-economic conditions, people from this area tend to frequently eat game meat and use the viscera to prepare 'farofa', a dish made of manioc flour mixed with giblets. The consumption of viscera greatly increases the likelihood of ingesting non-embryonated $C$. hepatica eggs, which may not cause infection but does result in enough antigen stimulation to trigger seropositivity at a 1:150 dilution. As reported in the present study (Table 2), the consumption of game meat is much less common in the urban population than in the riverine population. According to CAMARGO et al. ${ }^{4}, 91.7 \%$ of the riverine population had ingested viscera in the 15 days prior to the survey. In contrast, 27.2 to $41.1 \%$ of the urban population had ingested game meat in the 15 days preceding the study. This is the most likely explanation for the different rates of spurious infection (positive serology up to 1:150) between the riverine and urban populations.

Hepatic capillariasis is a disease with potentially high rates of contamination, low infectivity and low pathogenicity ${ }^{4}$. The low prevalence among humans can be explained not only by the low prevalence among rodents but also by the presence of running water and septic tanks in most dwellings, which prevent the exposure of humans to embryonated eggs.

The physical examination of the four residents with positive serology (IIF) for C. hepatica at the 1:400 dilution found no significant physiological alterations, such as jaundice, pain or visceromegaly. None of these four individuals had any abnormal laboratory findings (Table 5); similarly, results of their liver and bile duct ultrasound exams appeared to be within normal limits.

Abdominal pain and jaundice associated with hepatitis are clinical signs typically observed in humans infected with $C$. hepatica. CHOE et al. ${ }^{8}$ reported the case of a female 14-month-old child who presented with the triad of persistent fever, hepatomegaly and leukocytosis with eosinophilia. SAWAMURA et al. ${ }^{39}$ reported three cases of children aged between 18 and 36 months infected with the parasite; their disease 


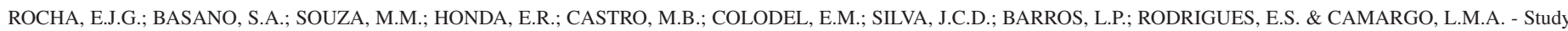
of the prevalence of Capillaria hepatica in humans and rodents in an urban area of the city of Porto Velho, Rondônia, Brazil. Rev. Inst. Med. Trop. Sao Paulo, 57(1): 39-46, 2015.

progressed to include symptoms of pain, choluria, jaundice, weight loss, fever and night sweats that only disappeared after antiparasitic treatments were administered. For these reasons, a C. hepatica infection must be considered as a differential diagnosis in cases of suspected hepatitis $\mathrm{A}, \mathrm{B}$ or $\mathrm{C}$ and leptospirosis, which are frequent in the studied region.

Future studies in other districts or older cities in the state may help answer these questions and better understand this zoonosis.

\section{CONCLUSIONS}

- Anatomopathological analyses of the livers of 50 rats captured in the periphery of dwellings in the study area and serological tests of 490 individuals in the same area using IIF were performed. A lower prevalence of $C$. hepatica infection was found in rodents in this study than in other studies in the literature. However infection of humans lies close to that found in other studies.

- Spurious infections characterized by positive serology (IIF) at a low serum dilution (i.e., 1:150) were detected among the residents. This finding suggests that humans have contact with $C$. hepatica eggs. This prevalence is much lower than the prevalence reported in the riverine population $\left(\mathrm{x}^{2}=154.6, p<0.0000001\right)$, most likely because the riverine population habitually consumes wild game viscera infected with $C$. hepatica, while consumption in the studied urban population is much lower.

- A low prevalence (approximately 1\%) of true infections was encountered. Infection with $C$. hepatica should be included in differential diagnosis lists along with viral hepatitis and leptospirosis. Importantly, the immediate treatment of capillariasis reduces its lethality ${ }^{8,39}$.

- Even though the prevalence of $C$. hepatica is low, the municipality should improve its urban areas to diminish the rat population.

- To better understand the situation encountered in this study (namely, the low prevalence of $C$. hepatica infection in an urban area of Porto Velho, the authors propose to 1) expand the study area, performing new assessments in other districts of the city or in Guarajá-Mirim, a nearby city as old as Porto Velho, and 2) increase the sample size by capturing and analyzing more rats.

\section{COMPETING INTERESTS}

All the authors declare no conflict of interest.

\section{AUTHORS' CONTRIBUTIONS}

EJGdR coordinated the research and wrote the article. LMAC: supervised the research and made the statistical analysis. SAB participated in the assessments and medical follow-ups of the residents during the data collection stage. MMdS participated in the supervision of the serological tests for the blood samples of residents. ERH performed the serological tests (IIF) for the serum blood samples of residents. MBdC performed the anatomopathological tests of the rat livers. EMC prepared the slides with the liver sections from rats experimentally infected by Capillaria hepatica in the laboratory for the IIF tests. JCDeS participated in field work, data collection and analysis. LPB participated in field work, data collection and analysis. ESR participated in field work, rat capture and preparation of the specimens (liver) in paraffin blocks. All authors read and approved the final manuscript.

\section{AUTHORS' INFORMATION}

EJGdR: Physician, first author of the study. Professor of Pediatrics, preceptor of the Internship in Outpatient Pediatrics, São Lucas Medical School in Porto Velho, state of Rondônia and Master's candidate at the Institute of Biomedical Sciences, University of São Paulo (Universidade de São Paulo - USP). LMAC: Physician. Researcher, PhD, Coordinator and Professor at the Institute of Biomedical Sciences-USP and at the São Lucas Medical School in Porto Velho. SAB: Physician. Professor of Medicine and preceptor of the course of Basic Health Care at São Lucas Medical School in Porto Velho, RO. PhD candidate at the Institute of Biomedical Sciences-USP. MMdS: Biologist. PhD and researcher at Fiocruz, state of Bahia. ERH: Pharmacist. PhD and researcher at the Central Laboratory for Public Health of Rondônia. MBdC: Veterinarian. $\mathrm{PhD}$ and professor at the Federal University of Brasília. EMC: Veterinarian. Professor and PhD Researcher at the Federal University of Mato Grosso. JCDeS: Student of the Scientific Initiation Program of the Graduate Program of Medicine at São Lucas Medical School, holder of a CNPq (National Council of Technological and Scientific Development)] grant. LPB: Scientific Initiation student of the Graduate Program of Medicine at São Lucas Medical School, holder of a CNPq grant. ESR: Scientific Initiation student of the Graduate Program of Biology at São Lucas Medical School, holder of a CNPq grant.

\section{LIST OF ABBREVIATIONS USED}

C. hepatica - Capillaria hepatica; ELISA - Enzyme-Linked Immunosorbent Assay; IBGE - Brazilian Institute of Geography and Statistics; IIF - Indirect immunofluorescence; N - sample size; PBS - Phosphate Buffered Saline; PVC- Polyvinyl chloride; R. norvegicus Rattus norvegicus; $R$. rattus - Rattus rattus; RPM - rotations per minute.

\section{RESUMO}

\section{Estudo da prevalência da Capillaria hepatica em humanos e roedores em área urbana da cidade de Porto Velho, Rondônia, Brasil}

Introdução: Capilaríase hepática é causada pela Capillaria hepatica (syn. Calodium hepaticum) (Bancroft, 1893), Travassos, 1915 (Nematoda, Trichinelloidea, Capillariidae), sendo uma zoonose comum entre roedores, porém rara em humanos. Setenta e dois casos humanos foram relatados na literatura mundial desde o primeiro caso descrito por MACARTHUR em 1924 $4^{17,27}$. O objetivo desse estudo é determinar a prevalência da Capillaria hepatica em humanos e roedores de área urbana da cidade de Porto Velho, capital de Rondônia, Brasil. Método: Após realizar um censo da área, 490 moradores foram aleatoriamente selecionados e assinaram termo de consentimento, foram colhidas amostras de sangue para testar anticorpos anti-Capillaria hepatica. Simultaneamente, ratos foram capturados para determinação da prevalência deste parasita através do exame histopatológico em cortes de fígado. Resultados: Foi encontrada entre humanos prevalência de 


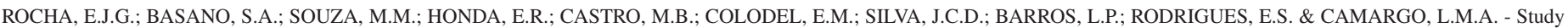
of the prevalence of Capillaria hepatica in humans and rodents in an urban area of the city of Porto Velho, Rondônia, Brazil. Rev. Inst. Med. Trop. Sao Paulo, 57(1): 39-46, 2015.

1,8\% de positividade para anticorpos específicos em diluição de 1:150, indicando exposição aos ovos do parasito; $0,8 \%$ desses também deram testes positivos quando seus soros sofreram diluição de 1:400, indicando infecção verdadeira. Nos ratos, a prevalência foi de $2 \%$. Conclusão: A prevalência encontrada para o parasito entre homens e roedores foi baixa. Enquanto a prevalência encontrada entre humanos esteve dentro dos limites encontrados na literatura, a prevalência entre roedores foi bem menor.

\section{ACKNOWLEDGEMENTS}

To Prof. Doctor Luis Marcelo Aranha Camargo for his availability and patience as supervisor of this study. For his generosity in sharing with me his knowledge and experience in the field of Medicine and Medical Research, and for always seeking to help me, guide me, and clarify any questions that arose - and they were many - during the conduction of the study.

To all colleagues who participated in the study, contributing with their knowledge and willingness to help and often giving up their time to support me. Without them, it would have been impossible to conduct this study. To the Institute of Biomedical Sciences-USP, one of the most well-renowned education institutions in Latin America, for allowing me to enroll as a Master's candidate. To the Faculdade de Medicina São Lucas for providing the necessary support for developing this work. To the students of the medicine program and related programs in the field of health who rolled up their sleeves and helped with the field work by collecting data and blood from the residents, capturing rats at the research site, preparing material from the rats for anatomopathological tests and preparing slides for serological tests. Without them, this research study would have taken much longer and all planned objectives may not have been reached. To the inhabitants of the district of Tucumanzal for their collaboration.

\section{REFERENCES}

1. Assis BC, Cunha LM, Baptista AP, Andrade ZA. A contribution to the diagnosis of Capillaria hepatica infection by indirect immunofluorescence test. Mem Inst Oswaldo Cruz. 2004;99:173-7.

2. Bhattacharya D, Patel AK, Das SC, Sikdar A. Capillaria hepatica, a parasite of zoonotic importance: a brief overview. J Commun Dis. 1999;31:267-9.

3. Bouchet F. Intestinal capillariasis in neolithic inhabitants of Chalain (Jura, France). Lancet. 1997;349(9047):256.

4. Camargo LM, Camargo JS, Vera LJ, Barreto PD, Tourinho EK, Souza MM. Capillariasis (Trichurida, Trichinellidae, Capillaria hepatica) in the Brazilian Amazon: low pathogenicity, low infectivity and a novel mode of transmission. Parasit Vectors. 2010;3:11.

5. Ceruti R, Sonzogni O, Origgi F, Vezzoli F, Cammarata S, Giusti AM, et al. Capillaria hepatica infection in wild brown rats (Rattus norvegicus) from the urban area of Milan Italy. J Vet Med B Infect Dis Vet Public Health. 2001;48:235-40.

6. Cheetham RF, Markus MB. Drug treatment of experimental Capillaria hepatica infection in mice. Parasitol Res. 1991;77:517-20.

7. Chieffi PP, Dias RM, Mangini AC, Grispino DM, Pacheco MA. Capillaria hepatica (Bancroft 1893) em murídeos capturados no município de São Paulo, SP, Brasil. Rev Inst Med Trop Sao Paulo. 1981;23:143-6.
8. Choe G, Lee HS, Seo JK, Chai JY, Lee SH, Eom KS, et al. Hepatic capillariasis: first case report in the Republic of Korea. Am J Trop Med Hyg. 1993;48:610-25.

9. Coimbra CE Jr, Mello DA. Enteroparasitas e Capillaria sp entre o grupo Surui, Parque Indigena Aripuanã, Rondonia. Mem Inst Oswaldo Cruz. 1981;76:299-302.

10. El Gebaly MW, Nassery SF, El Azzouni MZ, Hammouda NA, Allan SR. Effect of mebendazole and ivermectin in experimental hepatic capillariasis: parasitological, scanning electron microscopy and immunological studies. J Egypt Soc Parasitol. 1996;26:261-72

11. El Nassery S, El Gebaly MW, El Azzouni MZ, Hammouda NA, El Shenawie S, et al. Effect of mebendazole and ivermectin in experimental hepatic capillariasis B: histopathological and ultrastructural studies. J Egypt Soc Parasitol. 1996;26:315-26.

12. Farhang-Azad A. Ecology of Capillaria hepatica (Bancroft 1893) (Nematoda). II. Eggreleasing mechanisms and transmission. J Parasitol. 1977;63:701-6.

13. Fernandes A, Ferreira LF, Gonçalves ML, Bouchet F, Klein CH, Igushi T, et al. Intestina parasite analysis in organic sediments collected from a $16^{\text {th }}$-century Belgian archeological site. Cad Saude Publica. 2005;21:329-32.

14. Ferreira LA, Andrade ZA. Capillaria hepatica: cause of septal fibrosis of the liver. Mem Inst Oswaldo Cruz. 1993;88:441-7.

15. Fontes EM. Metodos de eutanásia (Euthanasia methods). Rev Port Ci Vet. 1995;40:104-9.

16. Freeman RS, Wright KA. Factors concerned with the epizootiology of Capillaria hepatica (Bancroft, 1893) (Nematoda) in a population of Peromyscus maniculatus in Algonquin Park, Canada. J Parasitol. 1960;46:373-82.

17. Fuehrer H-P, Igel P, Auer H. Capillaria hepatica in man: an overview of hepatic capillariosis and spurious infections. Parasitol Res. 2011;109:969-79.

18. Fugassa MH, Denegri GM, Sardella NH, Araujo A, Guichon RA, Martinez PA, et al. Paleoparasitological records in a canid coprolite from Patagônia, Argentina. J Parasitol. 2006;92:1110-3

19. Galvão VA. Estudos sobre Capillaria hepatica: uma avaliação do seu papel patogênico para o homem. Mem Inst Oswaldo Cruz. 1981;76:415-33.

20. Galvão VA. Capillaria hepatica, estudo da incidência em ratos de Salvador, Bahia e dados imunopatológicos preliminares. Rev Soc Bras Med Trop. 1976;10:333-7.

21. Galvão VA. Tentativa para detectar infecção pela Capillaria hepatica no homem. Rev Inst Med Trop Sao Paulo. 1979;21:231-6.

22. Gotardo BM, Andrade RG, Andrade ZA. Hepatic pathology in Capillaria hepatica infected mice. Rev Soc Bras Med Trop. 2000;34:341-6

23. Instituto Brasileiro de Geografia e Estatística. 2013. [cited 2013 Nov 23]. Available from: www.ibge.gov.br

24. Juncker-Voss M, Prost H, Lussy H, Ezenberg U, Auer H, Lassnig H, et al. Screening for antibodies against zoonotic agents among employees of the Zoologica Garden of Vienna, Schönbrunn, Austria. Berl Munch Tierarztl Wochenschr. 2004;117:404-9.

25. Lee C. The experimental studies on Capillaria hepatica. Kisaengchunhak Chapochi 1964;2:63-80.

26. Luttermoser GW. An experimental study of Capillaria hepatica in the rat and the mouse. Am J Hyg. 1938;27:321-40.

27. MacArthur WP. A case of infestation of human liver with Hepaticola hepatica (Bancroft, 1893) Hall, 1916; with sections from the liver. Proc R Soc Med. 1924;17:83-4

28. Meira JA. Nota sobre helmintos encontrados nos ratos de São Paulo. Brasil Med 1931;45:1212-6. 
ROCHA, E.J.G.; BASANO, S.A.; SOUZA, M.M.; HONDA, E.R.; CASTRO, M.B.; COLODEL, E.M.; SILVA, J.C.D.; BARROS, L.P.; RODRIGUES, E.S. \& CAMARGO, L.M.A. - Study of the prevalence of Capillaria hepatica in humans and rodents in an urban area of the city of Porto Velho, Rondônia, Brazil. Rev. Inst. Med. Trop. Sao Paulo, 57(1): 39-46, 2015.

29. Mobeli I, Arfaa F. Probable role of ground beetles in the transmission of Capillaria hepatica. J Parasitol. 1971;57:1144-5.

30. Monzon RB, Sanchez AR, Tadiaman AR, Najos AO, Valencia EG, De Rueda RR, et al. Comparison of the role of Musca domestica (Linnaeus) and Chrysomya megacephala (Fabricius) as mechanical vectors of helminthic parasites in a typical slum area of metropolitan Manila. Southeast Asian J Trop Med Public Health. 1991;22:222-8.

31. Nascimento I, Sadigursky M. Capillaria hepatica: alguns aspectos imunopatológicos da infecção espúria e da infecção verdadeira. Rev Soc Bras Med Trop. 1986;19:21-5.

32. Oliveira VC, Mello RP, D`Almeida JM. Dipteros muscoides como vetores mecânicos de ovos de helmintos em jardim zoológico, Brasil. Rev Saude Publica. 2002;36:614-20.

33. Pereira VG, França LC. Infecção humana por Capillaria hepatica. Relato de um caso tratado com êxito. Rev Hosp Clin Fac Med Sao Paulo. 1981;6:31-4.

34. Piazza R, Corrêa MO, Fleury RN. Sôbre um caso de infestação humana por Capillaria hepatica. Rev Inst Med Trop Sao Paulo. 1963;5:37-41.

35. Rocha GC, Lailheugue SH, Le Bailly M, Araújo A, Ferreira LF, Serra-Freire NM, et al. Paleoparasitological remains revealed by seven historic contexts from "Place d`Armes”, Namur, Belgium. Mem Inst Oswaldo Cruz. 2006;101(Suppl 2):43-52.

36. Ruas JL, Soares MP, Farias NA, Brum JG. Infecção por Capillaria hepatica em carnívoros silvestres (Licalopex gymnocercus e Cerdocyon thous) na região sul do Rio Grande do Sul. Arq Inst Biol (S Paulo). 2003;70:127-30.
37. Santos AB, Tolentino M Jr, Andrade ZA. Pathogenesis of hepatic septal fibrosis associated with Capillaria hepatica infection of rats. Rev Soc Bras Med Trop. 2001;34:503-6.

38. Santos RV, Coimbra CE Jr, Ott A. Estudos epidemiológicos entre grupos indígenas de Rondônia. III. Parasitoses intestinais nas populações dos vales dos rios Guaporé e Mamoré. Cad Saude Publica. 1985;1:467-77.

39. Sawamura R, Fernandes MI, Peres LC, Glavão LC, Goldani HA, Jorge SM, et al. Hepatic capillariasis in children: report of 3 cases in Brazil. Am J Trop Med Hyg. 1999;61:6427.

40. Solomon GB, Handley CO. Capillaria hepatica (Bancroft, 1893) in Appalachian mammals. J Parasitol. 1971;57:1142-4.

41. Spratt DM, Singleton GR. Hepatic capillariasis. In: Samuel WM, Pybus MJ, Kocan AA Parasitic diseases of wild mammals. $2^{\text {nd }}$ ed. Ames: Iowa State University Press; 2001. p. $365-79$.

42. Wright KA. Observation on the life cycle of Capillaria hepatica (Bancroft 1893) with a description of the adult. Can J Zool. 1961;39:167-82.

Received: 4 April 2014

Accepted: 29 May 2014 